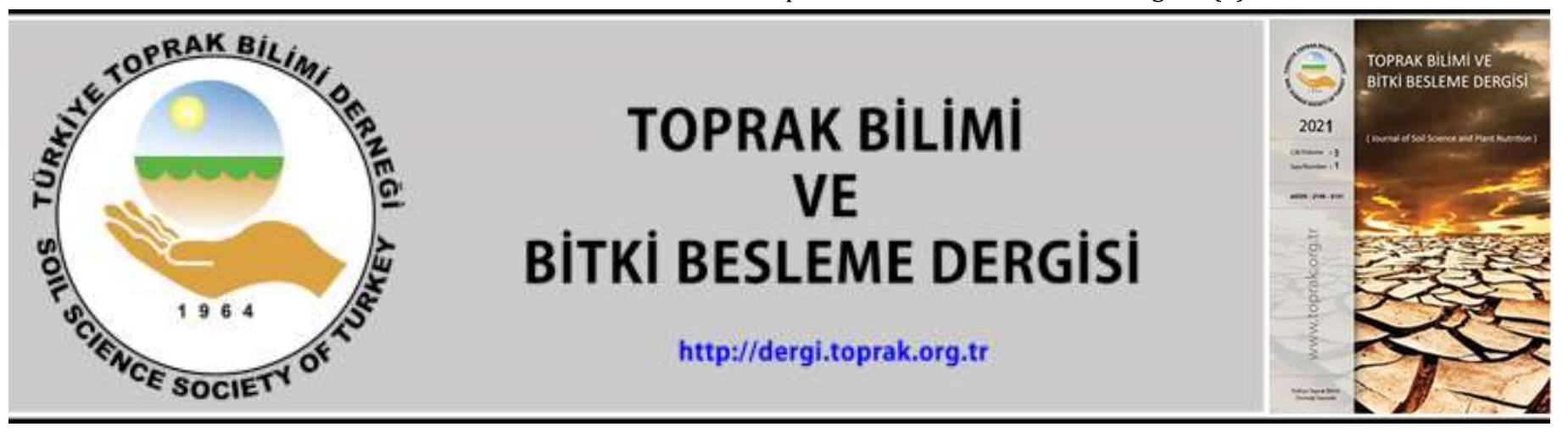

\title{
Çinko (Zn) uygulamalarının marul (Lactuca Sativa L.) bitkisinin bazı yaprak besin element içeriklerine etkisi
} (DBülent Yağmur*1, (DŞenay Aydın²

${ }^{1}$ Ege Üniversitesi Ziraat Fakültesi Toprak Bilimi ve Bitki Besleme Bölümü Bornova- İzmir ${ }^{2}$ Celal Bayar Üniversitesi Alașehir Meslek Yüksek Okulu Alașehir-Manisa

\begin{abstract}
Özet
Marul (Lactuca sativa L.) protein ve yağ oranı yok denecek kadar az, düşük kalorili, iştah açıcı bir bitkidir. Hem Türkiye'de hem de dünyada açıkta ve örtü altında yetiştirilmektedir. Ege, Marmara ve Akdeniz Bölgelerinde ticari marul üretimi Haziran, Temmuz, Ağustos hariç yılın her mevsiminde yapılabilmektedir. Çinko (Zn) bitkiler için önemli bir mikro elementtir ve çinko yetersizliği Dünya'da en sık görülen mikro element yetersizliğidir. Çinko yetersizliği bitkinin verim ve kalitesini etkilediği için gıda üretiminin sürdürebilirliliği açısından da önemlidir. Bu mikro element yetersizliğini önlemek için hem yapraktan hem de topraktan çinko uygulamaları yapılmaktadır. Bu çalışmada topraktan $\left(\mathrm{Zn}_{\mathrm{To}}=0 ; \mathrm{Zn}_{\mathrm{T} 1}=10 \mathrm{ppm} ; \mathrm{Zn}_{\mathrm{T} 2}=20 \mathrm{ppm} ; \mathrm{Zn}_{\mathrm{T} 3}=30\right.$ ppm) ve yapraktan farkl dozlarda çinko uygulamalarının ( $\mathrm{Zn}_{\mathrm{Y} 0}=0 ; \mathrm{Zn}_{\mathrm{Y} 1}=\%$ 0.10; $\mathrm{Zn}_{\mathrm{Y} 2}=\%$ 0.20; $\mathrm{Zn}_{\mathrm{Y}}=\% 0.303 \mathrm{kez}$ ) çinko sülfat formunda $\left(\mathrm{ZnSO}_{4} 7 \mathrm{H}_{2} \mathrm{O}\right) \mathrm{marul}$ bitkisinde bazı yaprak besin element içeriklerine etkisinin saptanması amaçlanmıștır. Sonuç olarak; hem toprak hemde yaprak Zn uygulamalarının bitkideki $\mathrm{Mg}, \mathrm{Zn}, \mathrm{Mn}$ ve $\mathrm{Cu}$ içerikleri üzerine istatiksel olarak önemli düzeyde $(\mathrm{P}<0.005)$ etkiler yaptığı saptanmıştır. Her iki uygulama yönteminde marul bitkisi için $\mathrm{Zn}_{\mathrm{T} 2}=20$ ppm ve $\mathrm{Zn}_{\mathrm{Y} 2}=\% 0.20$ önerilebilir.
\end{abstract}

Anahtar Kelimeler: Marul, çinko, gübre, toprak, yaprak, besin elementleri.

\section{The effect of applications of Zinc (Zn) on some leaf nutrient element contents of lettuce plant (Lactuca Sativa L.)}

\begin{abstract}
Lettuce (Lactuca sativa L.) is a low-calorie, appetizing plant with low protein and fat content. Lettuce is grown both in Turkey and in the world under the open cover. Commercial lettuce production in the Aegean, Marmara and Mediterranean regions can be made in all seasons of the year except June, July and August. Zinc (Zn) is an important micro element for plants and zinc deficiency is the most common micro element insufficiency in the world. Zinc insufficiency is also important for the sustainability of food production since it affects the yield and quality of the plant. In order to prevent the insufficiency of this micro element, zinc application from both soil and foliar applications are used. In this study, it was aimed to determine the effect of zinc applications on some leaf nutrient element contents in lettuce plant at different doses from soil $\left(\mathrm{Zn}_{\mathrm{To}}=0 ; \mathrm{Zn}_{\mathrm{T} 1}=10 \mathrm{ppm} ; \mathrm{Zn}_{\mathrm{T} 2}=20 \mathrm{ppm} ; \mathrm{Zn}_{\mathrm{T} 3}=30 \mathrm{ppm}\right)$ and leaf $\left(\mathrm{ZnY}_{0}=0 ; \mathrm{ZnY}_{1}=0.10 \%\right.$; $\mathrm{ZnY}_{2}=0.20 \%$; $\mathrm{ZnY}_{3}=0.30 \%$ as three times )in the form of $\mathrm{Zn} \mathrm{SO}{ }_{4} 7 \mathrm{H}_{2} \mathrm{O}$.As a result; the effects of the increasing doses of both soil and foliar applications on $\mathrm{Mg}, \mathrm{Zn}, \mathrm{Mn}$ and $\mathrm{Cu}$ contents of lettuce plant were determined to be statistically significant differences $(\mathrm{P}<0.05)$. In terms of both soil and foliar $\mathrm{Zn}$ applications $\mathrm{Zn}_{\mathrm{T} 2}=20 \mathrm{ppm}$ and $\mathrm{Zn}_{\mathrm{Y} 2}=0.20 \%$ can be recommended for Zn contents of lettuce plant.
\end{abstract}

Keywords: Lettuce, Zinc, fertilizer, soil, leaf, nutrient elements.

(C) 2021 Türkiye Toprak Bilimi Derneği. Her Hakkı Saklıdır

\section{Giriş}

Salata ve marul yaprağı yenen düşük kalorili ve iştah açıcı özelliği olan sebzeler arasında yer almaktadır. Protein ve yağ oranları yok denecek kadar azdır ve nişasta içermezler. Ancak iyi bir vitamin A ve C kaynağıdırlar. Yapraklarında antosiyanin içeren renkli yapraklı tipler karotenoidlerce zengindir. Bu nedenle salata ve marul kalp ve dolaşım sistemi sağlığı bakımından büyük öneme sahip antioksidan özelliği yüksek olan sebzelerdir. Ülkemizde çok eski yıllardan beri yetiştirilen yedikule tipi marullar A ve C vitaminleri bakımından diğerlerine göre daha zengindirler. Fakat Yedikule marulları son zamanlarda daha az

\footnotetext{
* Sorumlu yazar:

$\begin{array}{llll}\text { Tel. } & : \quad 0 \text { (535) } 2906548 & \text { Geliş Tarihi } \\ \text { E-posta } & : & \text { bulent.yagmur@ege.edu.tr } & \text { Kabul Tarih }\end{array}$

: 11 Mayis 2021

09 Haziran 2021

e-ISSN : $2146-8141$

DOI : $10.33409 /$ tbbbd .936190
} 
yetiştirilmekte ve kısa bir süre pazarlarda görülmektedir (Eşiyok; 2012). Diğer taraftan diyet sebzesi olan salata ve marul yaprakları \%94-95 oranında su içermektedir. Besleyici değerinin diğer sebzelere göre düșük olduğunun belirtilmesi yanında $100 \mathrm{~g}$ taze salata ve marul yaprağının 6-8 mg askorbik asit, 1-15 g ham protein, 0.2-0.4 g yağ ve 1.5-2.5 g karbonhidrat, 330 i.u. vitamin A 20-25 mg kalsiyum, $40 \mathrm{mg}$ fosfor ve $1.5 \mathrm{mg}$ demir içerdiği bildirilmektedir (Vural ve ark., 2000).

Baş salata ve marul (Lactuca Sativa L.) ülkemizde ve dünyanın birçok ülkesinde, açlkta ve örtü altı tarımında ekonomik olarak yetiştirilebilen sebzeler arasında yer almaktadır. Gün geçtikçe artan sebze ihtiyacının karşılanabilmesi için; üretim ve kaliteyi artıran, erkencilik ile yıl içindeki sebze yetiştiriciliğinin her bölgede devreye girmesi büyük katkılar sağlayacaktır. Özellikle ülkemizde baş salata ve marul üretimi özellikle 19851990 yıllarında artış göstermiş̧tir (Karataş ve ark., 1995). Ülkemizde salata ve marulun ticari boyutlardaki üretimi Ege, Marmara ve Akdeniz bölgelerinde Haziran ve Ağustos arasındaki aylar hariç yılın her mevsiminde yapılabilmektedir. Ancak en fazla gelir sağladığı Aralık-Şubat ayları üretimi Ege ve Güney bölgelerinde açık tarla koşullarında, diğer bölgelerde ise sera ve tünel altında yapılmaktadır (Vural ve ark., 2000). Ayrıca seralarda sürekli aynı türlerin yetiştirilmesi toprak yorgunluğuna yol açmaktadır. Bu nedenle marul sonbaharda diğer türlere alternatif olabilecek bir sebzedir. Ülkemizde yaklaşık 30.000 ha sera alanında \%96'sı biber, patlıcan, domates ve marul gibi sebzeleri yetiştirmek üzere kullanılmaktadır (Sevgican, 1999).

Marul toprak isteği bakımından seçici olmamakla birlikte kumlu-tın ve killi-tın bünyeli pH'ın 6-7 olduğu organik maddece ve bitki besin maddece zengin su tutma kapasitesinin iyi olduğu topraklarda kaliteli bir üretim oluşturmaktadır. Ağır karakterli ve derin olmayan topraklarda verim azalır ve bitki gelişimi yavaş olur. Özellikle toprak asitliği ve tuzluluğa karşı da çok hassastır (Eşiyok, 2012).

Tohum ekimi ve fide dikiminden önce toprak yapısına bağlı olarak dekara 3-5 ton çiftlik gübresi verim, kaliteyi olumlu etkiler. Özellikle hasat dönemine yakın verilen aşırı azotlu gübrelerin bitki yapraklarında biriken nitritin insan vücudunda olumsuz etki yaptığı saptanmıştır. Bu nedenle toprak analiz sonuçlarına ve kaldırılan ürüne göre gübreleme yapılmalıdır. Yapılan bir çalışmada kışlık üretimle dekardan $4500 \mathrm{~kg}$ ürün ile $26.2 \mathrm{~kg} \mathrm{~N}, 2.4 \mathrm{~kg} \mathrm{P}_{2} \mathrm{O}_{5}, 31.1 \mathrm{~kg} \mathrm{~K} \mathrm{~K}_{2}, 7.1 \mathrm{~kg}$ Ca ve $1.0 \mathrm{~kg} \mathrm{Mg}$, yazlık üretimle $5800 \mathrm{~kg}$ ürün ile $22.4 \mathrm{~kg} \mathrm{~N}, 1.5$ $\mathrm{kg} \mathrm{P}_{2} \mathrm{O}_{5}, 44.8 \mathrm{~kg} \mathrm{~K} 2 \mathrm{O}, 62 \mathrm{~kg} \mathrm{Ca}$ ve $1.7 \mathrm{~kg} \mathrm{Mg}$ topraktan kaldırmaktadır. Salata ve marul üretiminde toprak koşullarına ve yetiştirme dönemine bağlı olarak üreticiler dekara $15 \mathrm{~kg} \mathrm{~N}, 10 \mathrm{~kg} \mathrm{P}_{2} \mathrm{O}_{5}$ ve $15 \mathrm{~kg} \mathrm{~K}_{2} \mathrm{O}$ uygulamaktadırlar. Marul ve salatalarda verim birim alandan sebze olarak hasat edilen pazarlanabilir bitki sayısı olarak belirlenmekte, pazarlama adet olarak yapıldığı için verimde adet olarak verimektedir. Aile işletmelerinde bir dekar alandan ortalama 7000-8000 adet marul elde edilirken, örneğin damla sulama yapılarak yetiştirilen Yedikule marul çeşidinde 5000-6000 adet olarak pazarlanabilir marul elde edilmektedir. Pazarlanabilir marul adedi; yetiştirme dönemi, bitki sıklığı ve çeşit özelliğine bağlı olarak değişmektedir (Eşiyok, 2012).

TUIK (2021) verilerine göre ülkemizde 500151 ton marul (kıvırcık, göbekli, iceberg) üretilmekte, bunun 5747 tonu ihraç edilmektedir. Gerek ürün miktarının arttırılmasının, gerekse kalitenin iyileştirilmesinin en başta gelen şartı bitkilerin yeterli ve dengeli bir şekilde beslenmeleridir. Ülkemiz tarım alanlarında yıllardır tek taraflı N, P, K'lı kimyasal gübrelerin kullanılması, gübre ve ilaç bayilerinin önerdiği gübrelerin kullanılması, birim alandan alınan ürünün miktarının artması, yıkanma ile besin maddesi kayıpları, yeşil gübre ve çiftlik gübre kullanımının giderek azalması, toprak ve bitki analizlerine dayalı olmayan bilinçli bir gübreleme programının uygulanamaması, konvansiyonel (geleneksel) tarım yöntemlerinin sürdürülmesi gibi nedenlerle topraklarımızda bitki besin maddeleri dengesi giderek bozulmakta ve mikro elementlerin bitkilere faydalılığı azalmaktadır. Bunun bir sonucu olarak da son yıllarda dünyada ve ülkemizde yoğun şekilde tarım yapılan alanlarda mikro besin elementlerinden özellikle Zn (Çinko) noksanlığı görülmektedir (Çakmak ve ark., 1996; Torun ve Çakmak, 2004). Çinko noksanlığı kurak ve sıcak koşullarda pH, kireç, kil içeriğinin yüksek olduğu alanlarla birlikte düşük organik maddeye sahip, yıkanmanın fazla olduğu ve aşırı $P$ uygulanan topraklarda görülmektedir (Marschner, 1997). Topraklar toplam Zn miktarı yönünden çok zengin olmasına rağmen sorun toprakta Zn’un bitki köklerince kolaylıkla alınamamasıdır (Çakmak ve ark., 1996).

Çinko bitki metabolizmasında, fizyolojisinde, biyokimyasal işlevlerinde çok önemli görevi olan bir mikro besin elementidir (Marschner, 1997). Çinko'nun indolasetik asitin (IAA) bitki büyüme konilerinde sentezlenmesi için gerekli olduğu, bu hormonun eksikliğinde, bitkinin boğumlar arası mesafesinin kısalarak bitki büyüme ve gelişmesini gerilettiği bildirilmektedir. Ayrıca noksanlığında bitkilerde düşük gibberellin miktarı belirlenmiştir (Bergmann, 1993). 
Çinko (Zn) protein ve karbonhidrat metabolizmasında önemli fonksiyonları yanında, biyolojik membran stabilitesine etkinliği, enzim aktivite etme yeteneği, oksin sentezi gibi fonksiyonları nedeni ile direkt olarak verimi ve kaliteyi etkileyen bir mikro elementtir (Marschner, 1997; Mousavi ve ark., 2013)

Çinkonun yaprak, toprak ve katkılı kompoze gübre şeklinde olan uygulamalarının birçok kültür bitkilerinde hem verime hem de kaliteye olumlu yönde etkili olduğu yapılmış çalışmalarda saptanmıştır (Yağmur ve Aydın, 2013; Aydın ve ark., 2007; Hakerlerler ve ark., 1999; Eșiyok ve ark., 2001; Çakmak ve ark.,1996).

Çevresel etkenler yanında, bitkisel faktörler de (bitki çeşidi, kökü, yaşı, yaprak yapısı gibi) bitkilerin Zn beslenmesini belirlemede önemli bir faktördür (Mohsin ve ark., 2014). Bu bağlamda marul, çinko eksikliğine çok duyarlı ürünler arasında bulunmaktadır (Marschner, 1997).

Alaşehir yöresi bağ topraklarının çoğunda Zn eksikliği saptanmış bağ ve marulun gelişme parametreleri ve mineral beslenmesi ile Zn arasında önemli ilişkiler bulunmuştur (Aydın ve ark., 2007; Yağmur ve Aydın, 2013). Bu saptamaların ıșığında sunulan araştırma; Manisa ili Alaşehir ilçesinin belediye serasında yetiştirilen marul bitkisine topraktan ve yapraktan farklı dozlarda çinko uygulamalarının bazı makro ve mikro element ( $\mathrm{Ca}, \mathrm{Mg}, \mathrm{Fe}, \mathrm{Zn}, \mathrm{Mn}, \mathrm{Cu}$ ) içerikleri üzerine etkisini saptamak amacıyla gerçekleștirilmiştir.

\section{Materyal ve Yöntem}

Deneme Manisa ile Alaşehir ilçesi belediye arasında kontrollü olarak gerçekleștirilmiştir. Deneme materyali marul bitkisi yörede yaygın olarak yetiștiriciliği yapılan mor marul (Lactuca Sativa L.) çeşididir. Yüksekliği $25 \mathrm{~cm}$ genişliği $30 \mathrm{~cm}$ olan 32 adet silindirik plastik saksılarda yürütülen denemede, saksılara tartılarak doldurulan toprak Zn noksanlığı $(0.48 \mathrm{ppm})$ saptanan üretici tarlasından alınmıştır. Saksılara önce 2 marul fidesi dikilmiş daha sonra 1 bitki bırakılmıştır. Çizelge 1'de deneme toprağının fiziksel ve kimyasal analiz sonuçları verilmiștir. Denemede her bir saksı $6 \mathrm{~kg}$ toprak $+30 \mathrm{~g}$ perlit olacak șekilde doldurulmuş ve her saksıya 15:15:15 kompoze gübresinden (temel gübre olarak) 5 g olacak şekilde saksı toprağlyla birlikte homojen şekilde karıştırılarak verilmiştir. Deneme tesadüf parselleri desenine göre, topraktan ve yapraktan Zn uygulamaları şeklinde 4 seviyeli ve 4 tekerürlü gerçekleştirilmiştir. Topraktan çinko (Zn) uygulamaları çinko sülfat $\left(\mathrm{ZnSO}_{4} .7 \mathrm{H}_{2} \mathrm{O}\right)$ formunda tek seferde temel gübreleme olarak dikim zamanında $\left(\mathrm{Zn}_{\mathrm{TO}}=0 ; \mathrm{Zn}_{\mathrm{T} 1}=10\right.$ ppm; $\mathrm{Zn}_{\mathrm{T} 2}=20 \mathrm{ppm} ; \mathrm{Zn}_{\mathrm{T} 3}=30 \mathrm{ppm}$ ); yapraktan çinko uygulamaları ise üç kez 20 gün ara ile yine çinko sülfat $\left(\mathrm{ZnSO}_{4} 7 \mathrm{H}_{2} \mathrm{O}\right)$ formunda $\left(\mathrm{Zn}_{\mathrm{Y} 0}=0 ; \mathrm{ZnY}_{1}=\% 0.10 ; \quad \mathrm{Zn}_{\mathrm{Y} 2}=\% 0.20 ; \mathrm{Zn}_{\mathrm{Y}}=\% 0.30\right)$ verilmiştir. Topraktan ve yapraktan uygulamada kontrole uygulamasına $\mathrm{Zn}$ 'lu gübre uygulanmamış, sadece yapraktan uygulamada, kontrol saksılarındaki bitkilere su püskürtülmüş, diğer saksılardaki bitkilere ise yukarıdaki seviyelere göre Zn'lu çözeltiler verilmiştir. Saksılara verilen su miktarı başlangıçta su tutma kapasitesinin \% 60'ı olarak tartılmak suretiyle uygulanmış, vejetasyon döneminde su tutma kapasitesinin \%80'ine ulaşmıştır. Marul bitkisindeki yaprak örnekleri olgunlaşma döneminde olgun, sağlıklı yapraklardan alınmıștır (Mills and Jones, 1996; Kacar ve İnal, 2008). Yaprak örnekleri önce çeşme daha sonra saf suda yıkanarak ön temizlikleri yapılmıştır. $65-70^{\circ} \mathrm{C}$ de kurutma dolabında kurutulan örnekler öğütülerek analize hazır hale getirilmiştir (Kacar ve İnal, 2008). Analize hazır hale getirilen örneklerde yaş yakma yöntemi (Nitrik ve Perklorik asitle (1:4) uygulanarak elde edilen bitki ekstraklarında bitkinin Ca içeriği alev fotometresinde, $\mathrm{Mg}, \mathrm{Fe}, \mathrm{Zn}, \mathrm{Mn}$ ve $\mathrm{Cu}$ içerikleri ise AAS (Atomik Absorbsiyon Spektrofotometre) cihazında okunarak saptanmıştır (Mills ve Jones, 1996; Kacar ve İnal, 2008). Araştırmada kullanılan toprak örnekleri laboratuvarda uygun koşullarda kurutulduktan sonra 2 mm'lik elekten geçirilip fiziksel ve kimyasal analizleri uluslararası yöntemlere göre saptanmış, (Jackson, 1962; Çağlar, 1949; Bouyocous, 1955; Bremner, 1965; Lindsay ve Norvell, 1978; Kacar, 2009) Çizelge 1'de denemede kullanılan toprağın bazı fiziko- kimyasal analiz sonuçları verilmiştir.

Araştırmadan elde edilen verilerin değerlendirilmesinde TARIST paket programı kullanılmıştır (Açıkgöz ve ark., 1993).

Çizelge 1. Denemede kullanılan toprağın bazı fiziko-kimyasal analiz sonuçları

\begin{tabular}{lccl|llcc}
\multicolumn{1}{c}{ Analiz } & Birim & Sonuç & & Analiz & Birim & Sonuç \\
\hline pH & & 7,55 & Hafif alkali & Alınabilir Fosfor & (ppm) & 4,43 & Yetersiz \\
Toplam Tuz & $(\%)$ & 0,032 & Tuzsuz & Alınabilir Potasyum & (ppm) & 185 & Yetersiz \\
Kireç & $(\%)$ & 3,85 & Kireçli & Alınabilir Kalsiyum & (ppm) & 2360 & Yeterli \\
Kum & $(\%)$ & 68,40 & & Alınabilir Magnezyum & (ppm) & 275 & Yeterli \\
Silt & $(\%)$ & 24,00 & & Alınabilir Sodyum & (ppm) & 25 & Problemsiz \\
Kil & $(\%)$ & 7,60 & & Alınabilir Demir & (ppm) & 6,23 & Yeterli \\
Tekstür & & Kumlu-Tın & & Alınabilir Bakır & (ppm) & 1,27 & Yeterli \\
Organik Madde & $(\%)$ & 1,84 & Fakir & Alınabilir Çinko & (ppm) & 0,48 & Yetersiz \\
Toplam Azot & $(\%)$ & 0,070 & Orta & Alınabilir Mangan & (ppm) & 7,50 & Yeterli \\
\hline
\end{tabular}




\section{Bulgular ve Tartışma}

Topraktan ve yapraktan uygulanan çinkonun (Zn) farklı dozlarının marul bitkisinin bazı makro (Ca, $\mathrm{Mg}$ ) ile bazı mikro element ( $\mathrm{Fe}, \mathrm{Zn}, \mathrm{Mn}$ ve $\mathrm{Cu}$ ) içeriklerine ait ortalama değerler ve ortalamalar arasındaki farkların LSD testi ile kontrolü Çizelge 2'de verilmiștir

Çizelge 2 incelendiğinde topraktan $\mathrm{Zn}$ uygulamalarının; marul bitkisinin $\mathrm{Mg}$, $\mathrm{Zn}$ ve Mn içerikleri üzerine, yapraktan $\mathrm{Zn}$ uygulamalarının ise marul bitkisinin $\mathrm{Zn}$ ve $\mathrm{Cu}$ içerikleri üzerine istatistiksel olarak önemli düzeyde $(\mathrm{P}<0.05)$ etkiler yaptığı belirlenmiştir. Buna karşın her iki uygulama da bitkinin Ca ve Fe içerikleri ile topraktan $\mathrm{Zn}$ uygulamasının bitkinin $\mathrm{Cu}$, yapraktan $\mathrm{Zn}$ uygulama ise bitkinin $\mathrm{Mn}$ içerikleri üzerine istatiksel olarak etkili olmadığı gözlenmiştir.

Marul bitkisine topraktan $\mathrm{Zn}$ uygulamaları sonucunda elde edilen ortalama $\mathrm{Ca}, \mathrm{Mg}$, $\mathrm{Fe}, \mathrm{Zn}, \mathrm{Mn}$ ve $\mathrm{Cu}$ içerikleri sirasiyla \%1.30-1.52; \%0.51-0.62; 327.8-412.4ppm; 61.3-75.8 ppm; 61.8-82.0 ppm ve 13.0-14.2 ppm arasında değişmiştir. Buna karşılık yapraktan $\mathrm{Zn}$ uygulamaları ile marul bitkisinin $\mathrm{Ca}, \mathrm{Mg}, \mathrm{Fe}, \mathrm{Zn}, \mathrm{Mn}$ ve $\mathrm{Cu}$ değerleri sırasıyla \%1.17-1.28; \%0.68-0.72; 325.4-367.7 ppm; 58.2-79.5 ppm; 66.8-75.0 ppm ve 11.3-12.4 ppm arasında değiştiği görülmektedir (Çizelge 2). Fe ve Mn hariç en yüksek ortalama değerler genelde $\mathrm{Zn}_{\mathrm{T2}}$ $(20 \mathrm{ppm})$ ile $\mathrm{Zn}_{\mathrm{Y} 2}(\% 0.20)$ uygulamalarından elde edilmiştir. Demir besin elementi dışında çinko uygulanmayan kontrol saksılarda en düşük değerler saptanmıştır (Çizelge 2). Marul bitkisinin Mg, $\mathrm{Zn}$ ve Mn içerikleri üzerine topraktan $\mathrm{Zn}$ uygulamalarının etkisi istatistiki olarak önemli $(\mathrm{P}<0.05)$ bulunmuş ve kontrol uygulamasına göre artışların olduğu saptanmıștır (Çizelge 2). Yapraktan $\mathrm{Zn}$ uygulamalarının ise $\mathrm{Zn}$ ve $\mathrm{Cu}$ içeriklerine etkisinin istatistiki olarak önemli $(\mathrm{P}<0.05)$ olduğu ve kontrol uygulamasına göre önemli artışların olduğu saptanmıştır (Çizelge 2).

Çizelge- 2. Topraktan ve yapraktan çinko (Zn) uygulamalarının marul bitkisinin bazı makro ve mikro besin element içeriklerine (kuru madde de) etkisi

\begin{tabular}{|c|c|c|c|c|c|c|c|}
\hline \multicolumn{2}{|c|}{ UYGULAMALAR } & $\begin{array}{c}\text { Ca } \\
(\%)\end{array}$ & $\begin{array}{l}\text { Mg } \\
(\%)\end{array}$ & $\begin{array}{c}\text { Fe } \\
(\mathrm{ppm})\end{array}$ & $\begin{array}{c}\mathbf{Z n} \\
(\mathbf{p p m})\end{array}$ & $\begin{array}{c}\text { Mn } \\
(\mathbf{p p m})\end{array}$ & $\begin{array}{c}\mathrm{Cu} \\
(\mathrm{ppm})\end{array}$ \\
\hline \multirow{4}{*}{ 氮 } & $\mathbf{Z}_{\mathrm{T} 0}$ & 1.30 & $0.51 b^{*}$ & $\underline{412.4}$ & $61.3 \mathrm{c}$ & $61.8 \mathrm{~b}$ & 13.0 \\
\hline & $\mathbf{Z}_{\mathrm{T} 1}$ & 1.33 & $0.61 \mathrm{a}$ & 410.6 & $68.0 \mathrm{~b}$ & $72.1 \mathrm{ab}$ & 13.1 \\
\hline & $\mathbf{Z}_{\mathrm{T} 2}$ & $\underline{1.52}$ & $\underline{0.62} \mathrm{a}$ & 360.8 & $\underline{75.8 \mathrm{a}}$ & $76.1 \mathrm{ab}$ & $\underline{14.2}$ \\
\hline & $\mathbf{Z}_{\mathrm{T} 3}$ & 1.43 & $0.62 \mathrm{a}$ & 327.8 & $71.2 \mathrm{ab}$ & $\underline{82.0 \mathrm{a}}$ & 13.1 \\
\hline \multicolumn{2}{|l|}{ Ortalama } & 1.39 & 0.89 & 377.9 & 69.1 & 73.0 & 13.4 \\
\hline \multicolumn{2}{|l|}{ LSD $(\mathrm{P}<0.05)$} & n.s & 0.087 & n.s & 3.91 & 12.28 & n.s \\
\hline \multirow{4}{*}{ 究 } & $\mathrm{Z}_{\mathrm{Y} 0}$ & 1.17 & 0.68 & $\underline{367.7}$ & $58.2 \mathrm{c}$ & 66.8 & $11.3 \mathrm{~b}$ \\
\hline & $\mathbf{Z}_{\mathrm{Y} 1}$ & 1.18 & 0.72 & 366.8 & $62.2 \mathrm{bc}$ & 70.0 & $12.3 \mathrm{a}$ \\
\hline & $\mathrm{Z}_{\mathrm{Y} 2}$ & $\underline{1.28}$ & $\underline{0.72}$ & 341.9 & $\underline{79.5} \mathrm{a}$ & 72.0 & $\underline{12.4} \mathrm{a}$ \\
\hline & $\mathrm{Z}_{\mathrm{Y} 3}$ & 1.23 & 0.72 & 325.4 & $69.6 \mathrm{ab}$ & $\underline{75.0}$ & $12.4 \mathrm{a}$ \\
\hline \multicolumn{2}{|l|}{ Ortalama } & 1.27 & 0.71 & 350.5 & 67.4 & 70.9 & 11.6 \\
\hline \multicolumn{2}{|l|}{ LSD $(\mathrm{P}<0.05)$} & ns & n.s & n.s & 3.91 & n.s & 0.899 \\
\hline
\end{tabular}

${ }^{*}$ Aynı kolonda farklı harfle gösterilen ortalamalar arası fark istatistiksel olarak 0.05 seviyesinde önemlidir. n.s = Önemli değil.

Topraktan Zn'lu gübre uygulamasının marul bitkisinin $\mathrm{Zn}$ ve $\mathrm{Mn}$ içeriklerine, yapraktan Zn'lu gübre uygulamasının ise bitkinin $\mathrm{Zn}$ ve $\mathrm{Cu}$ içerikleri etkisi istatistiksel olarak önemli bulunurken, topraktan $\mathrm{Zn}$ 'lu uygulamasının marul bitkisinin $\mathrm{Fe}$ ve $\mathrm{Cu}$ içerikleri üzerine, yapraktan $\mathrm{Zn}$ 'lu uygulamasının ise marul bitkisinin Fe ve Mn içeriği üzerine etkisi istatiksel olarak önemli etkili olmadığı görülmektedir. Bitkide en yüksek $\mathrm{Zn}$ içeriğinin her iki uygulama yönteminde $\mathrm{Zn}$ 'un ikinci dozunda $\mathrm{Zn}_{\mathrm{T} 2}(20 \mathrm{ppm})$ ve $\mathrm{Zn}_{\mathrm{Y} 2}(\% 0.20)$ elde edildiği belirlenmiștir. İstatiksel olarak önemli olmasa da uygulamalar ve artan $\mathrm{Zn}$ dozları bitkinin $\mathrm{Mn}$ ve $\mathrm{Cu}$ içeriğini arttırmıştır. Topraktan ve yapraktan $\mathrm{Zn}$ uygulamalarında marul bitkisi yapraklarının en yüksek Fe içeriği kontrol uygulamasında belirlenmiş, her iki yöntemde de uygulanan Zn dozlarının artışı yaprakların Fe içeriğinde azalmaya sebep olmuştur. $\mathrm{Bu}$ durumun $\mathrm{Fe} \mathrm{Zn}$ arasındaki etkileşimin bir sonucu olduğu 
söylenebilir. Bununla beraber değişik araştırıcılar tarafından marul bitkisi için önerilen Fe kriter değerleri ile araştırmada saptanan Fe içerikleri klyaslandığında Fe beslenmesi yönünden herhangi bir sorunun olmadığı belirlenmiştir.

Trivedi ve Dhumal (2013) soğanın verim ve kalite parametreleri üzerine Hindistan'da 27 deneme kombinasyonunun topraktan ve yapraktan $\mathrm{Zn}$ ve $\mathrm{Fe}$ uygulamalarının etkisi incelemek için yaptıkları çalışmada Zn'yu topraktan 45t/ha olarak yapraktan 2,4-D (3ppm) ile birlikte vermişlerdir. Soğanın gelişimi, verimi ve kalitesi üzerine Zn uygulamasının Fe'den daha etkili olduklarını bildirmişlerdir.

Mohsin ve ark. (2014) hibrit mısırın gelişimi, dane kalitesi, verimliliği üzerine tohum uygulaması (\%1-\%2 Zn solüsyon) ile yaprak uygulamasını (\%1-\%2 Zn) yalnız ve kombinasyonları şeklinde 3 tekrarlamalı tesadüf blokları deneme desenine göre yaptıkları çalışmada mısırın dane verimi, bitki boyu, hasat indeksini ve $\mathrm{Zn}$ içeriğini yaprak uygulamasının daha etkili olduğunu saptamışlardır. Buna karşın dane protein içeriğinin ise uygulamalarının azalttığını bulmuşlardır.

Olesegun ve ark. (2014) Zambiya Alfasil topraklarında mısır ve buğday gelişimi üzerine Zn'un toprak (0-10-

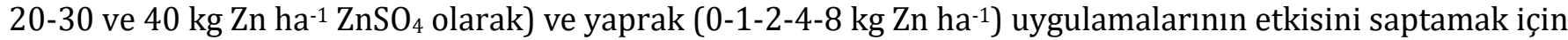
tarla denemesi kurmuşlardır. Sonuçta verimi topraktan Zn uygulamaları arttırırken, dane Zn içeriğini ise yapraktan Zn uygularının arttırdığını bulmuşlardır.

Hakerlerler ve ark. (1999)'da topraktan (0-100-200-300-400-500g $\mathrm{ZnSO}_{4} 7 \mathrm{H}_{2} \mathrm{O} /$ ağaç) ve yapraktan $3 \mathrm{kez} \mathrm{Zn}$ uygularak $\left(0-\% 0.05-\% 0.10-\% 0.15-\% 0.20 \mathrm{ZnSO}_{4} 7 \mathrm{H}_{2} \mathrm{O}\right)$ incirde yaptıkları çalıșmada topraktan uygulamanın sürgün uzunluğunu, boğum sayısını ve meyve sayısını artırdığını saptamışlardır. Aydın ve ark. (2007) yuvarlak çekirdeksiz üzüm çeşidine topraktan (0-15-30-45g $\mathrm{ZnSO}_{4} 7 \mathrm{H}_{2} \mathrm{O} /$ omca) ve yapraktan 3 kez çinko sülfat uygulayarak (0-\% 0.025-\%0.050-\%0.10 Zn) yaptıkları çalışmada taze meyve verimini, meyve eni ve boyunu, 100 tane ağırlığını, toplam eriyebilir kuru madde miktarını, yaprağın N, P, K ve Zn içeriklerini her iki uygulamanın da olumlu yönde etkilediğini saptamışlardır. Omca başına en yüksek verim topraktan $30 \mathrm{~g}$ $\mathrm{ZnSO}_{4} 7 \mathrm{H}_{2} \mathrm{O} /$ omca ile yapraktan \%0.05 $\mathrm{Zn}$ uygulamalarından sağlanmıştır.

Moghadam ve ark. (2012) İran'da buğdayda (Triticum aestivum) verim ve verim komponentleri üzerine yapraktan $\mathrm{Zn}$, B ve Cu uygulamalarının (0.1 ve2.0lt/ha) etkisini araştırmışlardır. Özellikle bor ve çinko uygulamalarının verim ve 1000 dane ağırlığına pozitif etki yaptığını bulmuşlardır.

Olgunlaşma döneminde marul bitkisinin yapraklarında makro elementlerden Ca için ; \%1.0-\%1.80; >\%0.88; \%1.4-2.0 ; \% 0.92; \%2.30-3.50 referans değerlerini, Winsor ve Schwarz, (1990); Hakerlerler ve ark. (1992); Reuter ve Robinson (1986); Anonim (1992); Mills ve Jones (1996) bildirmişlerdir. Hem topraktan hem yapraktan Zn uygulamalarının bitkinin Ca içeriği üzerine etkisi istatistiksel olarak önemli bulunmamakla birlikte marul bitkisi yapraklarının Ca içeriği Winsor ve Schwarz, (1990), Hakerlerler ve ark.(1992) ve Anonim (1992) tarafından önerilen kriter (referans) değerler ile kıyaslandığında elde edilen değerlerin verilen bu referens değerler arasında olduğu belirlenmiştir.

Olgunlaşma döneminde bitkinin Mg referans değerleri; \%0.24-0.48; \%0.25; \%0.30-0.70; \%0.32 olarak Winsor ve Schwarz, (1990); Hakerlerler ve ark.(1992); Reuter ve Robinson (1986) ve Anonim (1992) tarafindan verilmektedir. Hem topraktan hem yapraktan $\mathrm{Zn}$ uygulamaları sonucunda marul bitkisinin $\mathrm{Mg}$ içerikleri, farklı araştırıcılar tarafından verilen tüm referans (sınır) değerlerinin arasında veya üzerinde olduğu görülmektedir (Çizelge 2).

Bitkide her iki makro element için (Ca ve Mg) elde edilen verilerin toprak analiz sonuçları ile uyumlu olduğu, bitki beslenmesi açısından $\mathrm{Ca}$ ve $\mathrm{Mg}$ besin element içerikleri bakımından herhangi bir sorun olmadığı belirlenmiştir (Çizelge 1).

Winsor ve Schwarz (1990) tarafından olgunlaşma döneminde marul bitkisi yapraklarındaki Fe, $\mathrm{Zn}, \mathrm{Mn}$ ve $\mathrm{Cu}$ içerikleri için sıarasıyla; $>50$ ppm; $30-330$ ppm; $50-200$ ppm ve 10-25 ppm referans değerleri önerilmektedir. Hakerlerler ve ark. (1992) ise bitkinin yapraklarında $>55.9 \mathrm{ppm} ;>30.0 \mathrm{ppm} ;>22.0 \mathrm{ppm}$ ve $>$ 5.0 ppm Fe, Zn, Mn ve Cu değerlerini bildirmektedirler. Reuter ve Robinson (1986)'a göre; 50-500 ppm Fe; 25-150 ppm Zn; 30-200 ppm Mn ve 10-25 ppm Cu sınır değerleri verilmektedir. Mills ve Jones (1996)'ya göre Fe için 50-100 ppm; Zn için 25-250 ppm; Mn için; 15-250 ppm ve Cu için 8-25 ppm kriter değerleri bildirilmektedir.

Çizelge 2'den de görüleceği gibi her iki uygulama metodunda da marul bitkisi yapraklarının $\mathrm{Fe}, \mathrm{Zn}, \mathrm{Mn}$ ve $\mathrm{Cu}$ içerikleri farklı araştırıcılar tarafından verilen kriter (referans) değerler ile karşılaștırıldığında genellikle bu değerler ile uyumlu olduğu ve bitkinin mikro besin element içeriği bakımından herhangi bir beslenmesi 
sorununun olmadığı söylenebilir (Winsor ve Schwarz, 1990; Hakererler ve ark., 1992; Reuter ve Robinson, 1986; Mills ve Jones, 1996).

Ünsal ve ark. (2008) yaptıkları çalışmada alkalin topraklarda humik asit (0-40 kg da-1) ve çinko (0-2-4 kg da1 çinko sülfat olarak) uygulamalarının iki farklı nohut (Cicer arietinum L.) çeşidinin tane ve gövdesindeki bazı besin element içeriklerine etkisini araştırmışlardır. Humik asit ve çinko uygulamalarında tane ve gövde de Fe ve Zn içerikleri artarken çalışmamızda Fe içerikleri kontrole göre azalmaktadır (Çizelge- 2).

Hasani ve ark. (2012) nar meyvesinin verim, kalite (toplam suda erir kuru madde, titre edilebilir asitlik, antosiyan indeksi, yaprak alanı, meyve çapı) ve yapraktaki besin element içerikleri üzerine yapraktan çinko sülfat ve mangan sülfat uygulamalarının $(0 . \% 0,3$ ve $\% 0.6)$ etkisini belirlemek için yaptıkları çalışmada, $\% 0.3$ çinko sülfat uygulamasının daha etkili olduğunu saptamışlardır. Yapraktan Zn uygulaması ile araştırmamıza benzer şekilde yapraktaki Zn içeriği artmıştır. Buna karşın Mn içeriği çalışmamızdan farklı olarak azalmıştır. En uygun kombinasyon \%0.6 mangan sülfat ile \%0.3 çinko sülfat önerilmektedir. Çeşitli araştırıcılarının topraktan ve yapraktan $\mathrm{Zn}$ uygulayarak ıspanakta, buğdayda, mısırda ve marulda yaptıkları araştırmalarda da çalışmamıza benzer şekilde yapraktaki Zn içeriğinin arttığı saptanmıştır (Aref, 2011; Ranjbar ve Bahmaniar, 2007; Eşiyok ve ark., 2000).

\section{Sonuç}

$\mathrm{Bu}$ çalışmada, sera koşullarında saksıda topraktan ve yapraktan çinko $\left(\mathrm{ZnSO}_{4} 7 \mathrm{H}_{2} \mathrm{O}\right)$ uygulayarak yetiştirilen marul bitkisinde belli dozda Zn'lu gübreleme ile bazı yaprak besin element içeriklerinde artışların sağlandığı, topraktan ve yapraktan $\mathrm{Zn}$ uygulamalarının bitkinin $\mathrm{Mg}, \mathrm{Zn}$, $\mathrm{Mn}$ ve $\mathrm{Cu}$ içerikleri üzerine istatiksel olarak önemli düzeyde etkiler yaptığı saptanmıștır Her iki uygulamada da marul bitkisinin $\mathrm{Ca}, \mathrm{Mg}, \mathrm{Zn}$ ve $\mathrm{Cu}$ içeriğine $Z_{\mathrm{T} 2}$ ve $\mathrm{Zn}_{\mathrm{Y} 2}\left(20\right.$ ppm; \%0.20) seviyelerinin, $\mathrm{Mn}$ içeriği üzerine ise $\mathrm{Zn}_{\mathrm{T} 3}$ ve $\mathrm{Zn}_{\mathrm{Y} 3}$ dozlarının $\left(\mathrm{Zn}_{\mathrm{T} 3}=30\right.$ ppm; $\mathrm{Zn}_{\mathrm{Y} 3}=\% 0.30$ ) daha etkili olduğu saptanmıştır.

\section{Kaynaklar}

Açıkgöz N, Akkaş MKE, Maghaddom A, Özcan K, 1993. TARIST, PC'ler için istatistik kantitatif genetik paketi. Uluslararası Bilgisayar Uygulamaları Sempozyumu, 133, 15-19 Ekim, Konya.

Anonim, 1992. IFA World fertilizer usual manuel. International fertilizer industry association, Paris. Printed in Germany.

Aref F, 2011. Zinc and boron content by maize leaves from soil and foliar application of zinc sulfate and boric acid in zinc and boron deficient soils. Middle-East Journal of Scientific Research 7(4): 610-618

Aydın Ş, Yağmur B, Hakerlerler H, Çoban H, 2007. Effects of different types and levels of zinc sulphate applications in vineyard (Vitis vinifera L.) in a semiarid environment. Asian Journal of Chemistry 19(1): 555-563.

Bergmann W, 1993. Ernährungsstörungen bei Kulturpflanzen. Gustav Fischer Verlag Jena, Stuttgart.

Bouyoucus GJ, 1955. A recalibration of the hydrometer methods for making mechanical analysis of the soils. Agronomy Journal, 43:434-438.

Bremner JM, 1965. Total Nitrogen (Methods of Soil Analysis Part II, C.A. Black et al). American Soc. of Agr. Inc. Pub. Madison, Wisconsin, USA, pp. 1149-1176.

Çağlar KÖ, 1949. Toprak Bilgisi. Annkara Üniversitesi Ziraat Fakültesi Yayınları, Sayı:10. Ankara.

Çakmak İ, Torun B, Erenoğlu B, Kalaycı M, Yılmaz A, Ekiz H, Braun HJ, 1996. Türkiye'de toprak ve bitkilerde çinko eksikliği ve bitkilerin çinko eksikliğine dayanıklık mekanizmaları. Turkish Journal of Agriculture and Forestry, 20:13-23.

Eşiyok D, 2012. Kışlık ve yazlık sebze yetiştiriciliği. Meta Basım Matbaacılık, İzmir. 410s.

Eşiyok D, Yağmur B, Duman İ, Bozokalfa MK, 2000. çinko katkılı ve katkısız kompoze gübrelerin ıspanağın verim ve mineral madde içeriğine etkileri. Ege Üniversitesi Ziraat Fakültesi Dergisi 37 (2-3):101-108.

Hakerlerler H, Aydın Ş, İrget ME, Aksoy U, Tutam M, 1999. The effect of soil and foliage applied zinc on yield and quality of fig (Ficus carica L.cv sarılop) for drying, 5th International Meeting Type of Climate, p. 1071, July 4-9, Spain.

Hakerlerler H, Anaç D, Gül A, Saatçı N, 1992. Topraksız yetiştirme ortamlarının sera koşullarında yetiştirilen marulun azot fraksiyonlarına ve besin maddeleri miktarına etkileri. Ege Üniversitesi Ziraat Fakültesi Dergisi, 29(2-3):8794.

Hasani M, Zamani Z, Savaghebi G, Fatahi R, 2012. Effects of zinc and manganese as foliar spray on pomegranate yield, fruit quality and leaf minerals. Journal of Soil Science and Plant Nutrition. 12(3);471-480.

Jackson ML, 1962. Soil chemical analysis. Prentice Hall. Inc., New York.

Kacar B, 2009. Toprak Analizleri. Nobel Yayın Dağıtım (Genișletilmiș II. Baskı) No: 1387. Ankara, 467s.

Kacar B, İnal A, 2008. Bitki analizleri. Nobel yayınları. Yayın No: 1241. Fen Bilimleri,892. Nobel Yayın Dağıtım Ltd. Şti., Ankara, 892s. 
Karataş A, Akıncı İE, Akıncı S, Türkmen Ö, 1995. Açık arazi ve yüksek tünelde güz dönemi yetiştiriciliğine elverişli boş salata ve marul çeşitlerinin belirlenmesi. Türkiye II. Ulusal Bahçe Bitkileri Kongresi, (3):295-299, 3-6 Ekim, Adana.

Lindsay WL, Norvell WA, 1978. Development of a DTPA soil test for zinc, iron, manganese, and copper. Soil Science Society of America Journal, 42:421-428.

Marschner H, 1997. Mineral nutrition of higher plants.Institute of plant nutrition, University of Hohenheim. Academic Press. Inc., Sandiego, CA 9210, Germany. p. 889.

Mills HA, Jones JB, 1996. Plant Analysis Handbook II. Micro-Macro Publishing, Inc., Georgia, USA.

Moghadom MJ, Sharifabad HH, Noormohamadi G, Motahar SYS, Siadat SA, 2012. the effect of zinc, boron and copper foliar application, on yield and yield components in wheat (Triticum aestivum). Annals of Biological Research, 3(8):3875-3884.

Mohsin AU, Ahmad AUH. Farooq M, Ullah S. 2014. Influence of zinc application through seed treatment and foliar spray on growth, productivity and grain quality of hybrid Maize. The Journal of Animal \& Plant Sciences, 24(5):14941503.

Mousavi SR, Galavi M, Rezaei M, 2013. Zinc (Zn) importance for crop productiona review. International Journal of Agronomy and Plant Production, 4(1):64-68.

Olesegun A, Yerokun A, Chirwa M, 2014. Soil and foliar application of zinc to maize and wheat grown on a Zambian Alfisol. African Journal of Agricultural Research, 9(11):963-970.

Ranjbar GA, Bahmaniar, MA, 2007. Effects of soil and foliar application of zn fertilizer on yield and growth characteristics of bread wheat (Triticum aestivum L.) cultivars. Asian Journal of Plant Sciences 6(6):1000-1005.

Reuter D, Robinson JB, 1986. Plant analysis an inter pretation manual. Melbourne, Sydney, p.211.

Sevgican A, 1999. Örtüaltı Sebzeciliği Cilt I, Ege Üniversitesi Ziraat Fakültesi Basımevi, 302 s., İzmir.

Torun B, Çakmak B, 2004. Orta Anadolu Bölgesi'nde çinko noksanlı̆̆ı. Türkiye 3. Ulusal Gübre Kongresi, Tarım-SanayiÇevre, 521-534, 11-13 Ekim, Tokat.

Trivedi AP, Dhumal KN, 2013. Dhumal, Effect of soil and foliar applications of zinc and iron on the yield and quality of onion (Allium cepa L.) Bangladesh J. Agril. Res. 38(1):41-48.

TUIK, 2021. www.tuik.gov.tr. Erişim tarihi: 24.04.2021.

Ünsal H, Tüfekçi Ş, Gürbüz Kılıç Ö, 2008. Alkalin topraklarda humik asit ve çinko uygulamalarının iki farklı nohut (Cicer arietinum L.) çeşidinin tane ve gövdesindeki bazı besin element içeriklerine etkisi. 4. Ulusal Bitki Besleme ve Gübreleme Kongresi, 465-475, 8-10 Ekim, Konya.

Vural H, Eşiyok D, Duman İ, 2000. Kültür Sebzeleri (Sebze Yetiştirme), E.Ü. Basımevi, İzmir 440 s.

Winsor G, Adams P, 1987. Glasshouse Crops, (3):119-125.

Winsor GW, Schwarz ZM, 1990. Soilless culture for horticultural crop production. FAO Plant Production and Protection Papaer, No. 101,188p.

Yağmur B, Aydın Ş, 2013. Topraktan ve yapraktan çinko uygulamalarının marul (Lactuca sativa L.) bitkisinin gelişmesi ve bazı mineral madde kapsamı üzerine etkisi. Ege Tarımsal Araştırma Enstitüsü Dergisi, 23(2):36-43. 